\title{
Comparative Study of Outcome of Immediate vs Delayed Clamping of Umbilical Cord
}

\author{
Gaurav Agarwal ${ }^{1}$, Madhu Mathur ${ }^{2}$
}

\begin{abstract}
Anemia is a major health problem worldwide and is estimated to affect $24.8 \%$ of the global population in developed and developing countries. ${ }^{1}$ The primary cause of anemia, in $50 \%$ of cases $^{2}$ is iron deficiency, which is among the most important factors which contribute to the global burden of disease. ${ }^{33}$ Recently, delaying umbilical cord-clamping has been identified as one of four effective interventions to combat iron deficiency during the first 6 months of life. ${ }^{6}$ An additional $15-40 \mathrm{~mL}$ of blood volume per $\mathrm{kg}$ of birth-weight can be delivered to the infant through the umbilical cord by allowing placental transfusion of blood to complete. ${ }^{7,8}$ This can increase total blood volume by an estimated $30-50 \%,{ }^{7,8}$ thus providing an additional $30-75 \mathrm{mg}$ of iron at birth. ${ }^{7-9}$ Maximizing placental transfusion of blood takes approximately 3 minutes. ${ }^{10}$

Materials and Methods: This study was conducted on 150 near term (GA - 35 to 36.6 weeks) and 150 term (GA - 37 to 42 weeks) neonates delivered without any complication with uneventful pregnancies. All the patients were randomized for the timing of cord clamping at the time of birth. Results: Our primary outcome was the neonatal Hematocrit at $6 \mathrm{hrs}$ after delivery in all the groups. The secondary outcomes were neonatal hematocrit and neonatal bilirubin at 24 and $48 \mathrm{hrs}$, and any other abnormal neonatal outcome after delivery during hospital stay, maternal blood loss at the time of delivery, maternal postnatal hemoglobin and any abnormal maternal outcome after delivery (eg. PPH) during hospital stay. Discussion: The neonatal hematocrit levels were significantly higher in DCC groups whereas prevalence of neonatal anemia was significantly higher in ECC group. There was no significant difference in the neonatal bilirubin levels at 24 and $48 \mathrm{hrs}$, in both early and delayed cord clamping groups, in both near term and term neonates. There were no significant differences in the adverse early neonatal and maternal outcomes in both early and delayed cord clamping groups.
\end{abstract}

Keywords: Anemia, Maternal outcomes, Neonatal outcomes, Timing of cord clamping

Journal of Mahatma Gandhi University of Medical Sciences and Technology (2018): 10.5005/jp-journals-10057-0062

\section{INTRODUCTION}

Anemia is a major health problem worldwide and is estimated to affect $24.8 \%$ of the global population in developed and developing countries. ${ }^{1}$ The primary cause of anemia, in $50 \%$ of cases $^{2}$ is iron deficiency, which is among the most important factors which contribute to the global burden of disease. ${ }^{3}$ Iron deficiency during gestation and infancy can have devastating effects on both neural development and behavioral outcomes, and many of these negative consequences are not reversed by iron therapy. ${ }^{4}$ During the first six months of life, infants are largely dependent on the iron supply present at birth for growth and hemoglobin production. ${ }^{5}$

Recently, delaying umbilical cord-clamping has been identified as one of four effective interventions to combat iron deficiency during the first 6 months of life. ${ }^{6}$ An additional $15-40 \mathrm{ml}$ of blood volume per $\mathrm{kg}$ of birth-weight can be delivered to the infant through the umbilical cord by allowing placental transfusion of blood to complete. ${ }^{7,8}$ This can increase total blood volume by an estimated $30-50 \%,{ }^{7,8}$ thus providing an additional $30-75 \mathrm{mg}$ of iron at birth. ${ }^{7,8,9}$ Maximizing placental transfusion of blood takes approximately 3 minutes. ${ }^{10}$

Iron stores at birth correlate with iron stores at 6 to 12 months of age $^{11}$ and are determined by the transplacental iron transferred to the foetus and the blood transferred from the placenta at the time of delivery. This in turn, is determined by the timing of umbilical cord clamping. Policies for timing of cord clamping vary from time to time and place to place.

At the time of birth, the neonate is still attached to the mother via the umbilical cord, which is the part of the placenta. The neonate
${ }^{1}$ Resident, ${ }^{2}$ Professor and Unit Head

1,2 Department of Pediatrics, Mahatma Gandhi Medical College and Hospital, Jaipur, Rajasthan, India

Corresponding Author: Madhu Mathur, Professor and Unit Head, Department of Pediatrics, Mahatma Gandhi Medical College, Jaipur, Rajasthan, India, e-mail: Madhumathur07@gmail.com

How to cite this article: Agarwal G, Mathur M. Comparative Study of Outcome of Immediate vs Delayed Clamping of Umbilical Cord. J Mahatma Gandhi Univ Med Sci Tech 2018;3(1):25-30.

Source of support: Nil

Conflict of interest: None

is usually separated from the placenta by clamping the cord between two clamps. One clamp is placed close to the neonate's navel and the second is placed further along the umbilical cord; then the cord is cut between the two clamps. This takes place during the third stage of labour, which is the period of time from the birth of the neonate to the delivery of the placenta.

In practice, clamping the umbilical cord often takes place once cord pulsation has ceased or at least beyond the first minute following the birth of the baby. This intervention is likely to have most public health impact in countries like India with a high prevalence of anaemia during pregnancy and infancy.

Deferral of cord clamping provides about $80 \mathrm{~mL}$ of blood after $1 \mathrm{~min}$ and $100 \mathrm{ml}$ after 3 min of birth. ${ }^{12,13}$ This contributes $40-50 \mathrm{mg} /$ $\mathrm{kg}$ of extra iron to the neonate, which might prevent iron deficiency in the first year of life. ${ }^{14,15}$ Another potential benefit of delayed cord

() The Author(s). 2018Open Access This article is distributed under the terms of the Creative Commons Attribution 4.0 International License (https://creativecommons. org/licenses/by-nc/4.0/), which permits unrestricted use, distribution, and non-commercial reproduction in any medium, provided you give appropriate credit to the original author(s) and the source, provide a link to the Creative Commons license, and indicate if changes were made. The Creative Commons Public Domain Dedication waiver (http://creativecommons.org/publicdomain/zero/1.0/) applies to the data made available in this article, unless otherwise stated. 
clamping is increase in haematopoietic stem cells transferred to the newborn which might play a role in different blood disorders and immune conditions. ${ }^{16}$

When cord clamping is delayed at birth or the cord is milked, infants experience placental transfusion as whole blood is transferred (or transfused) from the placenta to the infant during the first few minutes of life. This blood contains not only volume and red blood cells but also millions of stem cells important in repairing tissue and building immune-competence. The red blood cells are a major source of iron during the first few months of life. When the cord is cut rapidly, the infant has no access to approximately 30 $\mathrm{ml} / \mathrm{kg}$ (of birth weight) of blood-about $30 \%$ of the fetal-placental blood volume. This additional blood volume may reduce the vulnerability of infants to inflammatory processes and provide protection against infection. . $^{17,18}$

Regarding maternal outcomes, there is a very little evidence to suggest that the timing of cord clamping has an impact on the incidence of postpartum haemorrhage (or peripartum blood loss) or any other adverse outcome.

This study was conducted with the objective to determine the effect of delayed cord-clamping on hematocrit level of neonates and to determine the clinical effects of delayed cord-clamping in neonates and mothers.

\section{Materials and Methods}

Randomized controlled trial was conducted at Mahatma Gandhi Medical College and Hospital, Jaipur between 1st January 2014 to 30th June 2015. 150 near term neonates (35-36.6 weeks of GA), and 150 term neonates (37-42 weeks of GA), delivered without any complication to the mother with uneventful pregnancies were included in the study.

\section{Inclusion Criteria}

- Venous blood collected at 6, 24 and 48 hours after birth from near term neonates (35-36.6 weeks of GA) and term neonates (37-42 weeks of GA).

- Maternal blood collected at 24 hrs after delivery.

\section{Exclusion Criteria}

- Mothers having diabetes mellitus, hypertension, heart disease or any other illness.

- Neonates with congenital malformations

- Congenital heart disease

- Hypoxia, respiratory distress syndrome

- Meconium aspiration syndrome (MAS)

- Neonatal Sepsis

- Persistent pulmonary hypertension (PPHTN)

- Large for GA or Small for GA

\section{Method of Randomization}

Computer generated random number sequences were placed in opaque sealed envelopes. The envelopes were opened when the women in labour (fulfilling the inclusion criteria), were about to deliver. After the delivery of the baby the cord was clamped according to the time specified for that group.

\section{Methodology}

This study was a randomized controlled trial, performed on 150 near term (35-36.6 weeks of gestational age) and 150 term neonates (37-42 weeks of gestational age), delivered without any complication to the mother with uneventful pregnancies.

After written parental consent, patients were randomly assigned for cord clamping within first $20 \mathrm{sec}$ ( group-1), at $1 \mathrm{~min}$ or between $45-75 \mathrm{sec}$ ( group-2) or at $3 \mathrm{~min}$ or $>120 \mathrm{sec}$ ( group3). Baseline maternal data with regard to age, parity, period of gestation, maternal antenatal hemoglobin and any medical illness, were recorded in all cases. The envelopes were opened when the women in labour (fulfilling the inclusion criteria), were about to deliver. At the time of delivery, an observer used a stopwatch to record the elapsed time before the umbilical cord was clamped. After delivery of the baby, the cord was clamped according to the time specified for that group. During this time, the newborn was held below but within $10 \mathrm{~cm}$ of the vaginal introitus and utmost care was taken to prevent hypothermia in the neonate by adequate drying and wrapping. Thereafter, the newborn was placed under a preheated radiant warmer in the delivery room.

Weight of the newborns at birth was noted. The newborns were examined thoroughly. Venous hematocrit values of neonates were measured at 6, 24 and 48 hours of life. Along with this, S. bilirubin values of neonates were measured at 24 and 48 hours after delivery. The sample was drawn from the antecubital vein of the neonate.

For the measurement of maternal blood loss, all vaginal blood was collected immediately after delivery by placing a pan and pad under the woman's buttocks until she was transferred to the postpartum ward. Maternal venous blood was collected in an EDTA vial for hemoglobin estimation after 24 hrs of delivery.

The primary outcome measure was the newborn venous hematocrit value at 6 hours after birth. Secondary outcome measures were neonatal hematocrit at 24 to 48 hours of age, plasma bilirubin level at 24 to 48 hours of age, early neonatal morbidity and mortality (tachypnea, respiratory grunting, respiratory distress, jaundice, seizures, sepsis, necrotizing enterocolitis, neonatal death), admission to the NICU, length of hospital stay, postpartum maternal blood-loss volume, and maternal hemoglobin value 24 hours after delivery.

Neonatal anemia was taken as venous hematocrit level of $<45 \%$ at 6 hours after birth and polycythemia in the newborn was taken as venous hematocrit of $>65 \%$.

Postpartum hemorrhage was considered as maternal blood loss at the time of delivery, $\geq 500 \mathrm{~mL}$.

\section{Statistical Analysis}

The data was coded and entered into Microsoft Excel spreadsheet. Analysis was done using SPSS version 20 (IBM SPSS Statistics Inc., Chicago, Illinois, USA) Windows software program. The variables were assessed for normality using the Kolmogorov Smirnov test. Descriptive statistics included computation of means and standard deviations. The Kruskal-Wallis test (for quantitative data within three groups) with post hoc Bonferroni test (to make more intra-groups comparison) was used for comparison of all clinical indicators. Chisquare test used for qualitative data whenever two or more than two groups were used to compare. Level of significance was set at $P=0.05$ ( $p=<0.05$ - significant, $p=<0.001$ - highly significant, $p=$ $<0.0001$ - very highly significant).

\section{Results}

The study was conducted on 150 near term (GA - 35 to 36.6 weeks) and 150 term (GA - 37 to 42 weeks) neonates delivered without 
any complication with uneventful pregnancies. All the patients were randomized for the timing of cord clamping at the time of birth. Both the major groups (i.e. Near Term and Term) were divided into 3 subgroups with respect to the timing of cord clamping. The 3 sub groups were-

1. Early cord clamping group-Timing of cord clamping $<20$ secs

2. 1 min cord clamping group-Timing of cord clamping $45-75$ secs.

3. 3 min cord clamping group-Timing of cord clamping $>120$ secs.

All the three subgroups were compared separately for term and near term neonates.

All the 3 subgroups (in each major group) were comparable in terms of maternal parity, gestational age, maternal antenatal hemoglobin and neonatal birth weight. Our primary outcome was the neonatal Hematocrit at $6 \mathrm{hrs}$ after delivery in all the groups. The secondary outcomes were neonatal Hematocrit \& neonatal Bilirubin at 24 and $48 \mathrm{hrs}$, and any other abnormal neonatal outcome after delivery during hospital stay, maternal blood loss at the time of delivery, maternal postnatal hemoglobin and any abnormal maternal outcome after delivery (eg. PPH) during hospital stay.

- In both the near term and term neonate groups, delayed cord clamping at 1 or 3 minutes after birth resulted in an increase in the venous hematocrit levels measured at $6 \mathrm{hrs}$, and a decreased prevalence of neonatal anemia.

- The neonatal hematocrit levels were significantly higher in DCC groups whereas prevalence of neonatal anemia was significantly higher in ECC group (Tables 1 to 3 ).

- There was no significant difference in the neonatal bilirubin levels at 24 and $48 \mathrm{hrs}$, in both early and delayed cord clamping groups, in both near term and term neonates.

- There were no significant differences in the early neonatal outcomes in both early and delayed cord clamping groups (near term and term neonates), with respect to the prevalence of neonatal polycythemia, respiratory problems, seizures, necrotising enterocolitis, sepsis and neonatal mortality (Table 4).

Table 1: Comparison of Neonatal HCT (\%) at 6 hrs among the groups

\begin{tabular}{|c|c|c|c|c|c|c|c|c|c|}
\hline & \multirow{2}{*}{$\begin{array}{l}\text { Timing of cord } \\
\text { clamping } \\
\text { (secs) }\end{array}$} & \multirow[b]{2}{*}{$n$} & \multirow[b]{2}{*}{$\begin{array}{l}\text { Mean } \\
(\%)\end{array}$} & \multirow[b]{2}{*}{$\begin{array}{l}\text { Std. } \\
\text { Deviation }\end{array}$} & \multicolumn{2}{|c|}{$\begin{array}{l}95 \% \text { Confidence } \\
\text { Interval for Mean }\end{array}$} & \multirow[b]{2}{*}{$\begin{array}{l}\text { Minimum } \\
\text { (\%) }\end{array}$} & \multirow[b]{2}{*}{$\begin{array}{l}\text { Maximum } \\
\text { (\%) }\end{array}$} & \multirow[b]{2}{*}{$p$ value } \\
\hline & & & & & $\begin{array}{l}\text { Lower } \\
\text { Bound }\end{array}$ & $\begin{array}{l}\text { Upper } \\
\text { Bound }\end{array}$ & & & \\
\hline \multirow{3}{*}{$\begin{array}{l}\text { Near } \\
\text { term }\end{array}$} & $<20$ & 50 & 50.19 & 4.56 & 48.90 & 51.49 & 42.20 & 67.20 & \multirow{3}{*}{$0.001(\mathrm{~S})$} \\
\hline & $45-75$ & 50 & 55.83 & 3.87 & 54.74 & 56.92 & 43.60 & 68.60 & \\
\hline & $>120$ & 50 & 60.90 & 4.16 & 59.71 & 62.10 & 49.20 & 68.40 & \\
\hline \multirow[t]{3}{*}{ Term } & $<20$ & 50 & 51.07 & 5.38 & 49.54 & 52.60 & 40.20 & 68.40 & \multirow{3}{*}{$0.001(\mathrm{~S})$} \\
\hline & $45-75$ & 50 & 55.93 & 4.309 & 54.69 & 57.17 & 45.60 & 69.60 & \\
\hline & $>120$ & 50 & 60.87 & 3.94 & 59.76 & 61.98 & 48.60 & 69.20 & \\
\hline
\end{tabular}

Test applied: Kruskal-Wallis test

Table 2: Comparison of Neonatal HCT (\%) at 24 hrs among the groups

\begin{tabular}{|c|c|c|c|c|c|c|c|c|c|}
\hline & \multirow{2}{*}{$\begin{array}{l}\text { Timing } \\
\text { of cord } \\
\text { clamping } \\
\text { (secs) }\end{array}$} & \multirow[b]{2}{*}{$n$} & \multirow[b]{2}{*}{$\begin{array}{l}\text { Mean } \\
\text { (\%) }\end{array}$} & \multirow[b]{2}{*}{$\begin{array}{l}\text { Std. } \\
\text { Deviation }\end{array}$} & \multicolumn{2}{|c|}{$\begin{array}{l}95 \% \text { Confidence } \\
\text { Interval for Mean }\end{array}$} & \multirow[b]{2}{*}{$\begin{array}{l}\text { Minimum } \\
\text { (\%) }\end{array}$} & \multirow[b]{2}{*}{$\begin{array}{l}\text { Maximum } \\
\text { (\%) }\end{array}$} & \multirow[b]{2}{*}{ pvalue } \\
\hline & & & & & $\begin{array}{l}\text { Lower } \\
\text { Bound }\end{array}$ & $\begin{array}{l}\text { Upper } \\
\text { Bound }\end{array}$ & & & \\
\hline \multirow[t]{3}{*}{ Near term } & $<20$ & 50 & 49.50 & 4.61 & 48.18 & 50.81 & 41.60 & 66.60 & \\
\hline & $45-75$ & 50 & 55.13 & 4.01 & 54.00 & 56.26 & 42.80 & 68.00 & $0.001(\mathrm{~S}$ \\
\hline & $>120$ & 50 & 60.13 & 4.59 & 58.81 & 61.45 & 44.80 & 68.20 & \\
\hline \multirow[t]{3}{*}{ Term } & $<20$ & 50 & 50.45 & 5.35 & 48.93 & 51.97 & 40.00 & 68.00 & \\
\hline & $45-75$ & 50 & 55.35 & 4.39 & 54.09 & 56.62 & 44.60 & 69.00 & $0.001(\mathrm{~S}$ \\
\hline & $>120$ & 50 & 59.85 & 4.05 & 58.71 & 60.99 & 44.40 & 68.40 & \\
\hline
\end{tabular}

Test applied: Kruskal-Wallis test

Table 3: Comparison of Neonatal HCT (\%) at $48 \mathrm{hrs}$ among the groups

\begin{tabular}{|c|c|c|c|c|c|c|c|c|c|}
\hline & \multirow{2}{*}{$\begin{array}{l}\text { Timing } \\
\text { of cord } \\
\text { clamping } \\
\text { (secs) }\end{array}$} & \multirow[b]{2}{*}{$n$} & \multirow[b]{2}{*}{$\begin{array}{l}\text { Mean } \\
(\%)\end{array}$} & \multirow[b]{2}{*}{$\begin{array}{l}\text { Std. Devia- } \\
\text { tion }\end{array}$} & \multicolumn{2}{|c|}{$\begin{array}{l}95 \% \text { Confidence Interval } \\
\text { for Mean }\end{array}$} & \multirow[b]{2}{*}{$\begin{array}{l}\text { Minimum } \\
(\%)\end{array}$} & \multirow[b]{2}{*}{$\begin{array}{l}\text { Maximum } \\
\text { (\%) }\end{array}$} & \multirow[b]{2}{*}{$p$ value } \\
\hline & & & & & $\begin{array}{l}\text { Lower } \\
\text { Bound }\end{array}$ & $\begin{array}{l}\text { Upper } \\
\text { Bound }\end{array}$ & & & \\
\hline \multirow{3}{*}{$\begin{array}{l}\text { Near } \\
\text { term }\end{array}$} & $<20$ & 50 & 49.10 & 4.64 & 47.78 & 50.41 & 41.00 & 66.20 & \multirow{3}{*}{$0.001(\mathrm{~S})$} \\
\hline & $45-75$ & 50 & 54.58 & 4.03 & 53.45 & 55.72 & 42.00 & 67.60 & \\
\hline & $>120$ & 50 & 59.68 & 4.57 & 58.36 & 60.99 & 44.80 & 68.00 & \\
\hline \multirow{3}{*}{ Term } & $<20$ & 50 & 50.08 & 5.306 & 48.57 & 51.59 & 39.60 & 67.40 & \multirow{3}{*}{$0.001(\mathrm{~S})$} \\
\hline & $45-75$ & 50 & 54.84 & 4.35 & 53.58 & 56.09 & 44.20 & 68.40 & \\
\hline & $>120$ & 50 & 59.33 & 4.02 & 58.25 & 60.51 & 44.00 & 68.00 & \\
\hline
\end{tabular}

Test applied: Kruskal-Wallis test 
Table 4: Table showing the Prevalence of Neonatal Polycythemia (HCT $>65 \%$ ) among the groups

\begin{tabular}{|c|c|c|c|c|c|}
\hline & \multirow{2}{*}{$\begin{array}{l}\text { Timing of cord } \\
\text { clamping } \\
\text { (secs) }\end{array}$} & \multirow[b]{2}{*}{$n$} & \multicolumn{3}{|c|}{$\begin{array}{l}\text { Prevalence of Neonatal Poly- } \\
\text { cythemia } \\
(H C T>65 \%)\end{array}$} \\
\hline & & & $\begin{array}{l}\text { At } 6 \text { hrs } \\
n / N(\%)\end{array}$ & $\begin{array}{l}\text { At } 24 \text { hrs } \\
n / N(\%)\end{array}$ & $\begin{array}{l}\text { At } 48 \mathrm{hrs} \\
\mathrm{n} / \mathrm{N}(\%)\end{array}$ \\
\hline \multirow{3}{*}{ Near term } & $<20$ & 50 & $1 / 50(2)$ & $1 / 50(2)$ & $0 / 50(0)$ \\
\hline & $45-75$ & 50 & $2 / 50$ (4) & $2 / 50$ (4) & $2 / 50(4)$ \\
\hline & $>120$ & 50 & $5 / 50(10)$ & $3 / 50(6)$ & $2 / 50$ (4) \\
\hline \multirow{3}{*}{ Term } & $<20$ & 50 & $2 / 50(4)$ & $1 / 50(2)$ & $1 / 50(2)$ \\
\hline & $45-75$ & 50 & $3 / 50$ (6) & $2 / 50$ (4) & $1 / 50(2)$ \\
\hline & $>120$ & 50 & $6 / 50(12)$ & $4 / 50(8)$ & $3 / 50$ (6) \\
\hline
\end{tabular}

- No significant difference was noted in the maternal blood loss at the time of delivery, maternal postnatal haemoglobin and the incidence of any abnormal maternal outcome (e.g. PPH), in both early and delayed cord clamping groups (near term and term neonates) (Table 7).

- In our study we did not find any significant difference in hematocrit values between 1 and 3 min groups (both DCC groups). So to conclude, 1 minute cord clamping seems to be safe and effective in decreasing the prevalence of neonatal anemia without any harmful effect in neonates or mothers in both near term and term neonates. We gain very little (nonsignificant difference in hematocrit values) by delaying cord beyond 1 minute. Our this observation needs to be confirmed by further larger studies.

- Near Term Neonates: The mean neonatal hematocrit at 6 hrs of delivery, was $50.19 \%$ (SD - 4.56) in early cord-clamping group, $55.83 \%$ (SD - 3.87) in the 1 min cord-clamping group and $60.90 \%$ (SD - 4.16) in the 3 min cord-clamping group. The difference in the hematocrit levels at $6 \mathrm{hrs}$, was statistically significant ( $p$ value -0.001 ).

- Term Neonates: The mean neonatal hematocrit at $6 \mathrm{hrs}$ of delivery was $51.07 \%$ (SD - 5.38) in early cord-clamping group, $55.93 \%$ (SD - 4.309) in the 1 min cord-clamping group and $60.87 \%$ (SD - 3.94) in the 3 min cord-clamping group. The difference in the hematocrit levels at $6 \mathrm{hrs}$ was statistically significant ( $p$ value -0.001 )

- NearTerm Neonates:The mean neonatal hematocrit at $24 \mathrm{hrs}$ of delivery, was $49.50 \%$ (SD - 4.61) in early cord-clamping group, $55.13 \%$ (SD - 4.01) in the 1 min cord-clamping group and $60.13 \%$ (SD - 4.59) in the 3 min cord-clamping group. The difference in the hematocrit levels at 24 hrs, was statistically significant ( $p$ value -0.001 )

- Term Neonates: The mean neonatal hematocrit at $24 \mathrm{hrs}$ of delivery, was $50.45 \%$ (SD - 5.35) in early cord-clamping group, $55.35 \%$ (SD - 4.39) in the 1 min cord-clamping group and 59.85\% (SD - 4.05) in the 3 min cord-clamping group. The difference in the hematocrit levels at $24 \mathrm{hrs}$, was statistically significant ( $p$ value -0.001 )

- Near Term Neonates: The mean neonatal hematocrit at $48 \mathrm{hrs}$ of delivery, was $49.10 \%$ (SD - 4.64) in early cord-clamping group, $54.58 \%$ (SD - 4.03) in the 1 min cord-clamping group and $59.68 \%$ (SD - 4.57$)$ in the 3 min cord-clamping group. The difference in the hematocrit levels was statistically significant ( $p$ value -0.001 ).

- Term Neonates: The mean neonatal hematocrit at 48 hrs of delivery, was $50.08 \%$ (SD - 5.306) in early cord-clamping group, $54.84 \%$ (SD - 4.35) in the 1 min cord-clamping group and $59.33 \%$ (SD - 4.02) in the 3 min cord-clamping group. The difference in the hematocrit levels was statistically significant ( $p$ value -0.001 )

- NearTerm Neonates:The prevalence of the neonates developing polycythemia (HCT $>65 \%)$, at $6 \mathrm{hrs}$, was $2 \%(1 / 50)$ in early cordclamping group, $4 \%(2 / 50)$ in the 1 min cord-clamping group and $10 \%(5 / 50)$ in the 3 min cord-clamping group. At $24 \mathrm{hrs}$, it was $2 \%(1 / 50)$ in early cord-clamping group, $4 \%(2 / 50)$ in the 1 min cord-clamping group and 6\% (3/50) in the 3 min cordclamping group. While at $48 \mathrm{hrs}$, it was $0 \%(0 / 50)$ in early cordclamping group, $4 \%(2 / 50)$ in the 1 min cord-clamping group and $4 \%(2 / 50)$ in the 3 min cord-clamping group.

- Term Neonates: The prevalence of the neonates developing polycythemia (HCT $>65 \%)$, at $6 \mathrm{hrs}$, was $4 \%(2 / 50)$ in early cord-clamping group, $6 \%(3 / 50)$ in the 1 min cord-clamping group and $12 \%(6 / 50)$ in the 3 min cord-clamping group. At 24 hrs, it was $2 \%(1 / 50)$ in early cord-clamping group, 4\% (2/50) in the $1 \mathrm{~min}$ cord-clamping group and $8 \%(4 / 50)$ in the $3 \mathrm{~min}$ cord-clamping group. While at $48 \mathrm{hrs}$, it was $2 \%(1 / 50)$ in early cord-clamping group, $2 \%(1 / 50)$ in the 1 min cord-clamping group and 6\% (3/50) in the 3 min cord-clamping group.

- Near Term Neonates: The mean neonatal bilirubin at 24 hrs of delivery, was $3.35 \mathrm{mg} / \mathrm{dl}$ (SD - 1.006) in early cord-clamping group, $3.39 \mathrm{mg} / \mathrm{dl}$ (SD - 0.82) in the $1 \mathrm{~min}$ cord-clamping group and $3.33 \mathrm{mg} / \mathrm{dl}$ (SD - 0.93) in the $3 \mathrm{~min}$ cord-clamping group. The difference in the bilirubin levels was statistically non-significant ( $p$ value -0.91 ).

- Term Neonates:The mean neonatal bilirubin at $24 \mathrm{hrs}$ of delivery, was $3.36 \mathrm{mg} / \mathrm{dl}$ (SD - 0.83) in early cord-clamping group, 3.42 $\mathrm{mg} / \mathrm{dl}$ (SD - 0.86) in the $1 \mathrm{~min}$ cord-clamping group and 3.47 $\mathrm{mg} / \mathrm{dl}(\mathrm{SD}-0.88$ ) in the $3 \mathrm{~min}$ cord-clamping group. The difference in the bilirubin levels was statistically nonsignificant ( $p$ value -0.8 )

In the study, the only abnormal neonatal outcome noted, was the respiratory problem in the form of Grunting and Tachypnoea, among all the groups. In the near term group, the incidence of the respiratory problem was $2 \%$ in early cord-clamping group, $2 \%$ in the 1 min cord-clamping group and $6 \%$ in the 3 min cord-clamping group. The difference in the outcome was statistically nonsignificant ( $p$ value -0.45 ). While in the term group, the incidence of the respiratory problem was $6 \%$ in early cord-clamping group, $6 \%$ in the 1 min cord-clamping group and $2 \%$ in the 3 min cordclamping group. The difference in the outcome was statistically non-significant ( $p$ value -0.49 ).

The incidence of abnormal maternal outcome in the form of postpartum hemorrhage (maternal blood loss at the time of delivery $\geq 500 \mathrm{ml}$ ) in different groups was, in near term cases $-4 \%$ in early cord-clamping group, $2 \%$ in the 1 min cord-clamping group and $6 \%$ in the 3 min cord-clamping group. The difference in the outcome was statistically non-significant ( $p$ value -0.11 ). While in term cases $-0 \%$ in early cord-clamping group, $4 \%$ in the 1 min cord-clamping group and $0 \%$ in the 3 min cord-clamping group. The difference in the outcome was statistically non-significant ( $p$ value -0.34 ).

\section{Discussion}

This randomized controlled trial was conducted with the objective to determine the effect of delayed cord-clamping on hematocrit level of neonates and to determine the clinical effects of delayed cord-clamping in neonates and mothers. 
Comparative Study of Outcome of Immediate vs Delayed Clamping of Umbilical Cord

Table 5: Comparison of neonatal bilirubin level at $24 \mathrm{hrs}$ among the groups

\begin{tabular}{|c|c|c|c|c|c|c|c|c|c|}
\hline & \multirow{2}{*}{$\begin{array}{l}\text { Timing } \\
\text { of cord } \\
\text { clamping } \\
\text { (secs) }\end{array}$} & \multirow[b]{2}{*}{$n$} & \multirow[b]{2}{*}{$\begin{array}{l}\text { Mean } \\
(m g / d l)\end{array}$} & \multirow[b]{2}{*}{$\begin{array}{l}\text { Std. Devia- } \\
\text { tion }\end{array}$} & \multicolumn{2}{|c|}{$\begin{array}{l}95 \% \text { Confidence Interval } \\
\text { for Mean }\end{array}$} & \multirow[b]{2}{*}{$\begin{array}{l}\text { Minimum } \\
(\mathrm{mg} / \mathrm{dl})\end{array}$} & \multirow[b]{2}{*}{$\begin{array}{l}\text { Maximum } \\
(\mathrm{mg} / \mathrm{dl})\end{array}$} & \multirow[b]{2}{*}{$p$ value } \\
\hline & & & & & $\begin{array}{l}\text { Lower } \\
\text { Bound }\end{array}$ & $\begin{array}{l}\text { Upper } \\
\text { Bound }\end{array}$ & & & \\
\hline \multirow{3}{*}{$\begin{array}{l}\text { Near } \\
\text { term }\end{array}$} & $<20$ & 50 & 3.35 & 1.006 & 3.07 & 3.64 & 2.10 & 5.40 & \multirow{3}{*}{0.91} \\
\hline & $45-75$ & 50 & 3.39 & 0.82 & 3.16 & 3.62 & 2.40 & 5.40 & \\
\hline & $>120$ & 50 & 3.33 & 0.93 & 3.06 & 3.60 & 2.10 & 5.60 & \\
\hline \multirow{3}{*}{ Term } & $<20$ & 50 & 3.36 & 0.83 & 3.12 & 3.59 & 2.20 & 5.40 & \multirow{3}{*}{0.8} \\
\hline & $45-75$ & 50 & 3.42 & 0.86 & 3.17 & 3.67 & 2.40 & 5.70 & \\
\hline & $>120$ & 50 & 3.47 & 0.88 & 3.22 & 3.72 & 2.20 & 5.40 & \\
\hline
\end{tabular}

Test applied: Kruskal-Wallis test

Table 6: Comparison of abnormal neonatal outcome till discharge among the groups

\begin{tabular}{|c|c|c|c|c|}
\hline & $\begin{array}{l}\text { Timing of cord } \\
\text { clamping } \\
\text { (secs) }\end{array}$ & $n$ & $\begin{array}{l}\text { Incidence of abnormal } \\
\text { neonatal outcome - } \\
\text { Grunting/Tachypnoea } \\
n / N(\%)\end{array}$ & $p$ value \\
\hline \multirow{3}{*}{ Near term } & $<20$ & 50 & $1 / 50(2)$ & \multirow{3}{*}{0.45} \\
\hline & $45-75$ & 50 & $1 / 50(2)$ & \\
\hline & $>120$ & 50 & $3 / 50(6)$ & \\
\hline \multirow{3}{*}{ Term } & $<20$ & 50 & $3 / 50(6)$ & \multirow{3}{*}{0.49} \\
\hline & $45-75$ & 50 & $3 / 50(6)$ & \\
\hline & $>120$ & 50 & $1 / 50(2)$ & \\
\hline
\end{tabular}

Test applied: Chi-square test

This study was conducted in the department of pediatrics in Mahatma Gandhi Medical College and Hospital, Jaipur, on 150 near term and 150 term neonates born without any complications to the neonate and the mother in an uneventful pregnancy. The primary outcome measure was the neonatal venous hematocrit value at 6 hours after birth. Secondary outcome measures were neonatal hematocrit at 24 to 48 hours of age, plasma bilirubin levels at 24 to 48 hours of age, early neonatal abnormal outcome (tachypnoea, respiratory grunting, respiratory distress, jaundice, seizures, sepsis, necrotizing enterocolitis, neonatal death), postpartum maternal blood-loss volume, maternal hemoglobin value at 24 hours after delivery and any abnormal maternal outcome in terms of PPH.

In our study, we found that mean neonatal hematocrit was significantly higher in delayed cord clamping group (1 and 3 minutes) as compared to early cord clamping group in both near term and term (Tables 1 to 3). The results were same as in previous studies of Wilson et al. (1941) ${ }^{19}$, Philip et al. $(1960)^{20}$, Lindercamp et al. (1992) ${ }^{21}$, Nelle et al. (1993) ${ }^{22}$, Chaparro et al. (2006) ${ }^{23}$, Cernadas et al. (2006) ${ }^{12}$, Jaleel et al. (2009) ${ }^{24}$, Shirvani et al. (2010). ${ }^{25}$

The prevalence of polycythemia (Hct $>65 \%$ ), in both near term and term neonates, at 6, 24 and $48 \mathrm{hrs}$ had some difference in ECC and DCC group but it was not statistically significant (Table 4).

As described in other studies, Andersson O et al. $(2013)^{26}$, Hay W et al. 2012, Halliday et al. 2009, Cernadas et al. (2006) ${ }^{12}$, van Rheenen et al. (2004) ${ }^{27}$, Lindercamp et al. (1992) ${ }^{21}$, Oxford Midwives Research Group (1991) ${ }^{28}$, there was no significant difference in the prevalence of polycythemia and no polycythemia related harmful effects were observed. Hutton et al. (2007) ${ }^{29}$ did find significantly higher rates of polycythemia associated with DCC, although they commented that no infant in any of the included studies in their review had been symptomatic. In the Cochrane report, the risk ratio of polycythemia by ECC compared to DCC was estimated to 0.39 ( $95 \% \mathrm{Cl} 0.12$ to 1.27$)$.
Table 7: Comparison of abnormal maternal outcome till discharge among the groups

\begin{tabular}{lllll}
\hline & $\begin{array}{l}\text { Timing of cord } \\
\text { clamping } \\
\text { (secs) }\end{array}$ & $n$ & $\begin{array}{l}\text { Incidence of } \\
\text { abnormal maternal } \\
\text { outcome }-P P H \\
n / N(\%)\end{array}$ & p value \\
\hline \multirow{4}{*}{ Near term } & $<20$ & 50 & $2 / 50(4)$ & \\
& $45-75$ & 50 & $1 / 50(2)$ & 0.11 \\
Term & $>120$ & 50 & $3 / 50(6)$ & \\
& $<20$ & 50 & $0 / 50(0)$ & 0.34 \\
& $45-75$ & 50 & $2 / 50(4)$ & \\
\hline
\end{tabular}

Test applied: Chi-square test

There was no significant difference in mean neonatal plasma bilirubin values as well as hyperbilirubinemia rates were similar in the 3 sub-groups of both major groups ( Table 5), which goes along with other authors' observations of Cernadas et al. (2006) ${ }^{12}$, van Rheenen et al. (2004) ${ }^{27}$, Oxford Midwives Research Group (1991) ${ }^{28}$, Nelson et al. (1980). ${ }^{30}$

Among the other neonatal outcomes (Table 6), evaluated in our study, the only abnormal neonatal outcome noted, was the respiratory problem in the form of Grunting and Tachypnoea, among all the groups. In the near term group, the incidence of the respiratory problem was $2 \%$ in early cord-clamping group, $2 \%$ in the 1 min cord-clamping group and $6 \%$ in the 3 min cord-clamping group. While in the term group, the incidence of the respiratory problem was $6 \%$ in early cord-clamping group, $6 \%$ in the $1 \mathrm{~min}$ cord-clamping group and $2 \%$ in the 3 min cord-clamping group. Respiratory disorders in all the newborns were transient. The difference was statistically insignificant amongst the sub-groups in both the major groups with $p$ values 0.45 and 0.49 respectively.

A transiently higher respiratory rate after DCC was shown by Yao et al. (1971) $)^{31}$, but Hutton et al. $(2007)^{29}$, Cernadas et al. $(2006)^{12}$ \& the Cochrane Report (2008) ${ }^{32}$ did not find any significantly higher risk of respiratory symptoms associated with DCC. In our study, we observed infants for signs of respiratory distress at 1 and 6 hours, and did not find any statistically significant differences between the two groups ( $p$ values 0.45 and 0.49 ).

With respect to maternal outcomes, no statistically significant differences were noted among the ECC and DCC groups. Maternal blood loss at the time of delivery, incidence of PPH (Table 7) and hemoglobin variations before and 24 hours after delivery,were similar among the 3 sub-groups with no statistically significant difference. These data are in agreement with what other authors have reported Andersson et al. $(2013)^{26}$, McDonald et al.; Cochrane 
Report (2008) ${ }^{32}$, Cernadas et al. (2006) ${ }^{12}$, Nelson et al. $(1980)^{30}$, Botha et al. (1968) ${ }^{33}$ and in disagreement with the belief that late clamping is associated with greater postpartum bleeding (Prendiville et al. $1988)^{34}$

In present study we concluded that in near term and term newborns, cord clamping at 1 or 3 minutes after birth resulted in an increase of venous hematocrit levels measured at 6, 24 and 48 hours, within physiologic ranges. There was a decreased prevalence of neonatal anemia without any harmful effect in newborns or mothers. Thus, this intervention seems to be safe and effective and could be implemented easily.

Till now, the two DCC groups - 1 minute and 3 minutes, have hardly ever been compared, but as we found in our study that there is no statistically significant difference in the various results amongst the two groups, there is no need to unnecessary delay the cord clamping till 3 minutes. But still it needs to be further evaluated with larger studies.

\section{References}

1. Benoist B, McLean E, Egli I, Cogswell M. Worldwide prevalence of anaemia 1993-2005: WHO Global Database on Anaemia. Geneva: World Health Organization, 2008.

2. World Health Organization, UNICEF, United Nations University. Iron Deficiency Anaemia: Assessment, Prevention, and Control. A Guide for Programme Managers. Geneva: WHO (WHO/NHD/01.3), 2001.

3. World Health Organization. The World Health Report 2002: Reducing Risks, Promoting Healthy Life. Geneva: WHO, 2002.

4. Lozoff B, Georgieff M. Iron deficiency and brain development. Semin Pediatr Neurol. 2006;13:158-165.

5. Kleigman RM. Nelson Textbook of Pediatrics. 18th ed. Philadelphia: Saunders; 2007.

6. Stoltzfus RJ. Research needed to strengthen science and programs for the control of iron deficiency and its consequences in young children. J Nutr. 2008;138:2542-2546.

7. Levy T, Blickstein I. Timing of cord-clamping revisited. J Perinat Med. 2006;34:293-297.

8. Dewey KG, Chaparro CM. Session 4: Mineral metabolism and body composition iron status of breast-fed infants. Proc Nutr Soc. 2007;66:412-422.

9. Weckert $\mathrm{R}$, Hancock $\mathrm{H}$. The importance of delayed cord clamping for Aboriginal babies: a life-enhancing advantage. Women Birth. 2008;21:165-170.

10. Yao AC, Moinian M, Lind J. Distribution of blood between infant and placenta after birth. Lancet. 1969;2:871-873.

11. Gupta R, Ramji S. Effect of delayed cord clamping on iron stores in infants born to anemic mothers: a randomized controlled trial. Indian Pediatr.2002;39:130-135.

12. Ceriani Cernadas JM, Carroli G, Pellegrini L, Otano L, Ferreira M, Ricci $C$, et al. The effect of timing of cord clamping on neonatal venous hematocrit values and clinical outcome at term: a randomized, controlled trial. Pediatrics. 2006;117:e779-786.

13. Labour. In: Campbell $S$ and Lees $C$, eds. Obstetrics by Ten Teachers. 17th ed. Arnold 2000; 101-139.

14. Pisacane A. Neonatal prevention of iron deficiency. BMJ 1996;312:136137.
15. Michaelsen KF, Milman N, Samuelson G. A longitudinal study of iron status in healthy Danish infants: effects of early iron status, growth velocity and dietary factors. Acta Paediatr 1995; 84: 1035-1044.

16. Wardrop CA, Holland BM. The roles and vital importance of placental blood to the newborn infant. J Perinat Med 1995; 23: 139-143.

17. Molitoris BA, Sutton TA. Endothelial injury and dysfunction: role in the extension phase of acute renal failure. Kidney Int. 2004;66:496-499.

18. Rajnik M, Salkowski CA, Thomas KE, Li YY, Rollwagen FM, Vogell SN.Induction of early inflammatory gene expression in a murine model of nonresuscitated, fixed-volume hemorrhage. Shock. 2002;17:322-328.

19. Wilson EE, Windle WF, Alt HL. Amer. J. Dis. Child.1941; 62: 320.

20. Lanzkowsky P. Effects of early and late clamping of umbilical cord on infant\&\#39;s haemoglobin level. British Medical Journal. 1960;17771782 .

21. Linderkamp O, Nelle M, Kraus M, Zilow EP. The effect of early and late cord-clamping on blood viscosity and other hemorheological parameters in full- term neonates. Acta Paediatr.1992;81:745-750.

22. Nelle M, Zilow EP, Kraus M, Bastert G, Linderkamp O. The effect of Leboyer delivery on blood viscosity and other hemorheologic parameters in term neonates. Am J Obstet Gynecol.1993;169:189-193

23. Chaparro CM, Neufeld LM, Tena AG, Eguia-Liz CR, Dewey KG. Effect of timing of umbilical cord clamping on iron status in Mexican infants: a randomised controlled trial. Lancet. 2006;367:1997.

24. Jaleel R, Deeba F, Khan A. Timing of umbilical cord clamping and neonatal haematological status. JPMA.2009;59(7):468-470.

25. Shirvani F, Radfar M, Hashemieh M, Soltanzadeh MH, Khaledi $\mathrm{H}$, Mogadam MA. Effect of Timing of Umbilical Cord Clamp on Newborns' Iron Status and its Relation to Delivery Type. Archives of Iranian Medicine 2010; 13: 420-424

26. Andersson O, Hellström-Westas L, Andersson D, Clausen J, Domellöf M. Effects of delayed compared with early umbilical cord clamping on maternal postpartum hemorrhage and cord blood gas sampling: a randomized trial. Acta Obstet Gynecol Scand. 2013 May;92(5):567574.

27. Van Rheenen $P$, BrabinBJ. Late umbilical cord clamping as an intervention for reducing iron deficiency in term infants in developing and industrialised countries: a systematic review. Annals of Tropical Medicine 2004;24(1):3-16.

28. Oxford Midwives Research Group. A study of the relationship between the delivery to cord clamping interval and the time of cord separation. Midwifery. 1991;7:167-176.

29. Hutton EK, Hassan ES. Late vs early clamping of the umbilical cord in full-term neonates: systematic review and meta-analysis of controlled trials. JAMA. 2007;297:1241-1252.

30. Nelson NM, Enkin MW, Saigal S, Bennett KJ, Milner R, Sackett DL. A randomized clinical trial of the Leboyer approach to childbirth. $\mathrm{N}$ Engl J Med. 1980;302:655-660.

31. Yao AC, Lind J, Vuorenkoski V. Expiratory grunting in the late clamped normal neonate. Pediatrics. 1971;48:865-870.

32. McDonald SJ, Middleton P. Effect of timing of umbilical cord clamping of term infants on maternal and neonatal outcomes. Cochrane Database Syst Rev. 2008;2:CD004074.

33. Botha M. The management of the umbilical cord in labour. S Afr JObstet Gynaecol. 1968;6:30-33.

34. Prendiville WJ, Harding JE, Elbourne DR, Stirrat GM. The Bristol third stage trial: active versus physiological management of third stage of labour. BMJ 1988;297(6659):1295-1300. 